\title{
Influence of Morphological Characters of Chickpea Varieties on Damage by Gram Pod Borer (Helicoverpa armigera Hubner)
}

\author{
D. Rakshith Roshan* and S.V.S. Raju \\ Department of Entomology \& Agricultural Zoology, \\ Institute of Agricultural Sciences, Banaras Hindu University, Varanasi-221 005 (U. P.) India \\ *Corresponding author
}

\section{A B S T R A C T}

\begin{tabular}{|l|}
\hline Ke y w or d s \\
Chickpea, Physico- \\
morphic, Varieties, \\
Gram pod borer
\end{tabular}

\section{Introduction}

Chickpea [Cicer arietinum (L.)], commonly known as Bengal gram, "Chana" or gram, originated from South Western Asia, is one of the most important pulse crop grown in India with an area of 95.39 lakh hectares producing 90.75 lakh tones during 2016-17 (Anonymous, 2017). Although all the pulses occupy a unique position in Indian agriculture as well as throughout the world, chickpea is considered as "king of pulses". It is valued for its nutritive seeds with high protein content, 25.3-28.9\%, after dehulling (Hulse, 1991). The chickpea seeds are eaten fresh as green vegetables while Dhal (split chickpea without its seed coat) can be dried, fried, roasted or boiled, and used to make thick soup, bread or ground into flour for making snacks, sweets, and condiments (Hulse,1991). The productivity of chickpea is limited by a complex of interacting biotic and abiotic factors. The key pest pod borer, 
Helicoverpa armigera (Hubner) is the major biotic constraint and causes serious damage during fruit development (Naresh and Malik, 1986; Deka et al., 1987). Its larvae eat leaves, growing shoots and many pods during their entire life span. A full grown larva feeds on grains by making a hole in the pod and thrusts its head inside pod, while its posterior part of the body remains outside. A single larva can consume 30-40 pods in its life time (Taggar and Singh, 2012) and hence can cause 10-35 per cent reduction in pod yield (Singh et al., 2004). Host plant resistance through varietal resistance remains as the most effective tool in integrated pest management which is compatible with other methods of control with no additional cost to growers. Several chickpea genotypes with less susceptibility to $H$. armigera (the genotypes that have the capability to recover from pod borer damage) have been identified in the past (Dua et al., 2005, Sharma et al., 2005). Among various plant characters, physico-morphic characters govern the extent of damage caused by insect pests. The characters like trichomes, thick seed coat may reduce the feeding preference of $H$. armigera. In the present experiment the effect of the morphological characters of chickpea viz., plant height, number of primary branches, number of pods per plant, 100 grain dry weight, trichome density on pod, pod length and pod width were studied in relation to the per cent pod damage.

\section{Materials and Methods}

A field experiment was carried out at Agricultural farm, Institute of Agricultural Sciences, Banaras Hindu University, Varanasi during 2015-16 and 2016-17 to study the role of various physico-morphic characters of chickpea against pod damage by $H$. armigera . Eighteen chickpea varieties viz., RSG-991, BG-256, L-550, RADHEY, GNG-1581, PUSA-209, HC-3, CSJ-515, GNG-146, C235, PUSA-261, CSJD-884, RSG-10, DIGVIJAY, GNG-1491, AKGS-1, GCP-101 and ANNIGERI-1 were procured form IIPR, Kanpur were raised in randomized block design with three replications. Standard agronomic practices as per recommendation were followed and no insecticidal sprays were conducted in experimental plot. The larval population per 5 plants and per cent pod damage was recorded on standard week basis and overall mean percentage was calculated. The following physico-morphic (morphological/biophysical) characters of the plant were studied during pod formation stage of crop, when the plants were still green.

\section{Plant height}

Five plants were randomly selected in each variety and their height was measured from the ground level to the top of the plant canopy with the help of an ordinary meter scale.

\section{Number of primary branches}

The branches arising from the basal node were counted from randomly selected five plants in each test variety and the average number of primary branches per plant was calculated.

\section{Number of pods per plant}

At maturity, data for number of pods per plant was recorded from five randomly selected plants in each test entry and then the average number was worked out. Only filled pods were included in the count.

\section{Grain dry weight}

Three samples of hundred grains of each test entry from each plot were taken and weighed in grams using an electric balance and average was worked out.

\section{Hair density per $\mathrm{cm}^{2}$ on pods}

Three pods each from five randomly selected plants of each entry were taken and then hair 
density was noted under stereoscopic microscope, which was converted into $\mathrm{cm}^{2}$.

\section{Pod size}

\section{Pod length and pod width}

Three mature and full grown pods were taken each from five randomly selected plants of each test entry. The pod length and pod width was determined by Vernier caliper.

\section{Results and Discussion}

\section{Plant height}

\section{5-16}

Maximum average plant height during pod formation stage (Table 1) was attained by the variety CSJ-515 $(53.63 \mathrm{~cm})$, RSG-10 (51.33 $\mathrm{cm})$ and L-550 $(50.67 \mathrm{~cm})$ which were statistically at par and the corresponding per cent pod damage was 19.14, 22.49 and $20.75 \%$, respectively. An average plant height observed with variety DIGVIJAY was $42.74 \mathrm{~cm}$ which was closely followed by ANNIGERI-1 (43.74 cm) and RADHEY $(44.52 \mathrm{~cm})$ which were at par. Lowest average plant height among all the treatments was attained by the variety GNG-1581 $(31.78 \mathrm{~cm})$ which was significantly differed from all the test varieties, including AKGS-1 $(35.58 \mathrm{~cm})$ and GCP-101 (40.62cm).

\section{6-17}

Average plant height during 2016-17 was ranged from $51.84 \mathrm{~cm}$ to $33.42 \mathrm{~cm}$ (Table 2). Susceptible check variety ANNIGERI-1 attained $44.71 \mathrm{~cm}$ height and the corresponding per cent pod damage was observed to be $21.92 \%$. However, maximum average plant height was recorded on varieties CSJ-515 $(51.84 \mathrm{~cm})$, GNG-146 $(49.33 \mathrm{~cm})$ and RSG-10 $(48.64 \mathrm{~cm})$ which were at par. Lowest average plant height of $33.42 \mathrm{~cm}$ was again recorded with GNG-1581 also differed significantly with plant height of rest of all varieties including AKGS-1, DIGVIJAY and PUSA209 with plant height of $38.27 \mathrm{~cm}, 39.45 \mathrm{~cm}$ and $40.37 \mathrm{~cm}$, respectively.

The plant height was observed to be correlated as positive and non significant with per cent pod damage during 2015-16 $(\mathrm{r}=+0.313)$ and 2016-17 ( $\mathrm{r}=+0.175)$ (Table 3).

These results, however, were concurrently in support with the studies of Sanap and Jamadagni (2005) who reported that the preference or non-preference for oviposition on chickpea by female moth may be due to its varying behavioral response possibly due to different canopy structure of the plants.

\section{Primary branches}

\section{5-16}

During 2015-16, primary branches per plant were shown in Table 1. Maximum number of primary branches per plant was recorded on PUSA-261 (7.47 branches/plant) which was highest and differed significantly from CSJD884 (6.73 branches/plant) ANNIGERI-1 (6.61 branches/plant) and PUSA $-209 \quad(6.47$ branches/plant). A lowest number of 3.42 primary branches per plant were observed on variety RSG-991 followed by varieties BG256 and GCP-101 with 4.61 and 4.83 primary branches per plant, respectively.

\section{6-17}

Mean number of primary branches recorded on the ANNIGERI-1, susceptible check variety was 6.17 branches per plant (Table 2). However, among different varieties, maximum number of primary branches per plant was recorded on PUSA-261 (6.85 branches/plant) followed by C-235 (6.56 branches/plant) and 
CSJD-884 (6.23 branches/plant) which differ significantly among themselves and also with susceptible check variety. A lower mean number of primary branches were observed on GNG-1491 (3.67 branches/plant), RSG-991 (3.84 branches/plant) and BG-256 (4.25 branches/plant).

Correlation studies revealed that the primary branches were correlated as non significantly positive with per cent pod damage during 2015-16 ( $\mathrm{r}=0.091)$ while a negative and non significant correlation was observed during 2016-17 $(r=-0.014)$ (Table 3).

These results are in corroboration with finding of Hasan et al., (2008) who obtained a significant positive correlation between pod borer infestation and number of branches plant $^{-1}$.

\section{No. of pods per plant}

\section{5-16}

There was significant difference in number of pods per plant during crop maturity in different varieties (Table 1) with maximum 35.62 pods on BG-256 and 34.84 on RSG-10 which were at par with each other followed by GNG-146 (31.84), HC-3 (29.80), L-550 (29.67), AKGS-1 (26.87), PUSA-209 (26.82) and ANNIGERI-1 (26.72). Lowest number of pods per plant was recorded on varieties C235 (16.36) and GNG-1581 (20.41) and was at par with each other.

\section{6-17}

During 2016-17, mean number of pods per plant among the varieties was ranged between 33.67-17.84 pods per plant (Table 2). Among the varieties, maximum number of pods per plant was recorded on RSG-10 (33.67) which was not significantly different to number of pods observed on BG-256 (32.38) and GNG146 (29.87). A lowest number of 20.81 and
17.84 pods per plant recorded on varieties DIGVIJAY and C-235, respectively.

During two years of experimentation a non significant positive correlation was observed between per cent pod damage and number of pods per plant (Table 3 ).

\section{0 grain weight}

\section{5-16}

Average 100 grain weight of the varieties under study varied from 19.84 to $25.54 \mathrm{~g}$ (Table 1). The susceptible check variety i.e. ANNIGERI-1 had recorded 100 grain weight of $21.44 \mathrm{~g}$ and the highest 100 grain weight was recorded in the L-550 (25.54g) followed by $\mathrm{HC}-3 \quad(24.67 \mathrm{~g})$, CSJ-515 (23.15g) and RSG-991 (23.16g). Whereas 100 grain weight of $20.44 \mathrm{~g}$ was recorded on GNG-1491, GNG1581 and C-235. Lowest 100 grain weight was observed from PUSA-261 (19.85g) and AKGS-1 (19.84g) varieties and the average grain weight differed significantly from the 100 grain weight of rest of all varieties.

\section{6-17}

During 2016-17, 100 grain weight of varieties under study was shown in the Table 2. Highest 100 grain weight was recorded in the L-550 $(26.89 \mathrm{~g})$ which was significantly different from susceptible check ANNIGERI-1 (23.86) and closely followed by HC-3 (26.17g), RSG991 (25.74), CSJ-515 (25.33g) and ANNIGERI-1 (23.86). Again, lowest 100 grain weight of $18.33 \mathrm{~g}$ was recorded in varieties PUSA-261 and AKGS-1 and this weight of 100 grains differed significantly from the 100 grain weight of all the test varieties.

A positively non significant correlation was observed between 100 grain weight and per cent pod damage during 2015-16 $(\mathrm{r}=0.162)$ and 2016-17 ( $\mathrm{r}=0.056)$ (Table 3$)$. 


\section{Hair density per centimeter on pods}

\section{5-16}

The number of trichomes per $\mathrm{cm}^{2}$ of pods was highest on C-235 (435.21 per $\mathrm{cm}^{2}$ ) and differed significantly with other varieties. The corresponding per cent pod damage was 9.78\% (Table 1). Hair density on GNG-1581, DIGVIJAY, RSG-991 and GNG-1491 was observed to be $385.67,380.45,372.45$, and 370.45 per $\mathrm{cm}^{2}$. Lowest trichome density of 261.56 trichomes per $\mathrm{cm}^{2}$ leaf area was recorded on variety PUSA-209 and the corresponding per cent pod damage was $24.54 \%$ which was followed by trichome density on RADHEY (265.11 per $\mathrm{cm}^{2}$ ), HC-3 (286.14 per $\mathrm{cm}^{2}$ ) RSG-10 (296.26 per $\left.\mathrm{cm}^{2}\right)$ and AKGS-1 (344.26 per $\left.\mathrm{cm}^{2}\right)$.

\section{6-17}

The number of trichomes on pods varied significantly between various varieties and the highest number of trichomes per $\mathrm{cm}^{2}$ pod area were again recorded on variety C-235 (497.71 per $\mathrm{cm}^{2}$ ) which differed significantly from the trichome density observed on the susceptible check ANNIGERI-1 (368.11 per $\left.\mathrm{cm}^{2}\right)$. C-235 was closely followed by trichome density on pods of GNG-1491 (426.75 per $\mathrm{cm}^{2}$ ), GNG1581 (413.18 per $\mathrm{cm}^{2}$ ), PUSA-261 (401.67 per $\left.\mathrm{cm}^{2}\right)$ and RSG-991 (399.84 per $\left.\mathrm{cm}^{2}\right)$.

A Significantly lowest number of 307.26 trichomes per $\mathrm{cm}^{2}$ was recorded on PUSA-209 and next lowest pod hair density of 324.67, 327.14 and 331.82 trichomes per $\mathrm{cm}^{2}$ was recorded on the RADHEY, HC-3 and DIGVIJAY, respectively (Table 2).

From the correlation analysis it was observed that the trichome density on pods was correlated as significantly negative with per cent pod damage during 2015-16 $(\mathrm{r}=-0.911)$ and 2016-17 $(\mathrm{r}=-0.619)$.
Similar findings of high trichome density contributing to low per cent pod damage was reported by Girija et al., (2008), Hasan et al., (2008), Hossain et al., (2008), Kanchana et al., (2005) and Shahzad et al., (2005).

\section{Pod length (cm)}

\section{5-16}

An average pod length of $1.90 \mathrm{~cm}$ was recorded on the L-550 which was at par with pod length of $1.89 \mathrm{~cm}, 1.86 \mathrm{~cm}$ and $1.84 \mathrm{~cm}$ recorded on GNG-1491, HC-3 and DIGVIJAY, respectively (Table 1). These varieties were closely followed by the BG-256 $(1.78 \mathrm{~cm})$, RSG-991 $(1.76 \mathrm{~cm})$ and CSJ-515 $(1.64 \mathrm{~cm})$. A lowest average pod length of $1.40,1.42,1.49$ and $1.51 \mathrm{~cm}$ was observed on the varieties GNG-1581, CSJD-884, AKGS-1 and GCP-101, respectively and no significant difference in pod length was observed among all the test varieties.

\section{6-17}

During 2016-17, pod length of the various varieties under study was observed to be in a range of 1.33 to $1.85 \mathrm{~cm}$ (Table 2) and the difference of mean was observed to be statistically non significant.

Highest pod length of $1.85 \mathrm{~cm}$ was recorded with the pods of $\mathrm{HC}-3$ followed by L550(1.84cm), RSG-991 (1.82 cm), GNG-146 $(1.82 \mathrm{~cm})$, PUSA-261 $(1.78 \mathrm{~cm})$ and BG-265 $(1.76 \mathrm{~cm})$. The lowest average pod length was recorded from the pods of variety CSJD-884 $(1.33 \mathrm{~cm})$ and $\mathrm{GNG}-1581(1.39 \mathrm{~cm})$.

Pod length and per cent pod damage was correlated as negatively non significant during first year $(\mathrm{r}=-0.073)$ and second year $(\mathrm{r}=-$ 0.126 ) of experiment (Table 3 ). 


\section{Int.J.Curr.Microbiol.App.Sci (2018) 7(12): 2025-2033}

Table.1 Morphological characters of chickpea varieties/genotypes during 2015-16

\begin{tabular}{|c|c|c|c|c|c|c|c|c|c|}
\hline Varieties/Genotypes & $\begin{array}{c}* \text { Overall } \\
\text { mean no. of } \\
\text { larvae per } 5 \\
\text { plants }\end{array}$ & $\begin{array}{l}\text { *Overall } \\
\text { mean per } \\
\text { cent pod } \\
\text { damage }\end{array}$ & $\begin{array}{l}{ }^{*} \text { Plant } \\
\text { height } \\
(\mathrm{cm} .)\end{array}$ & $\begin{array}{c}\text { * Primary } \\
\text { branches/plant }\end{array}$ & $\begin{array}{c}{ }^{*} \text { No. of } \\
\text { pods/plant }\end{array}$ & $\begin{array}{l}{ }^{*} 100 \text { grain } \\
\text { weight (g.) }\end{array}$ & $\begin{array}{c}\text { Average } \\
\text { pod } \\
\text { trichome } \\
\text { density } / \mathrm{cm}^{2}\end{array}$ & $\begin{array}{l}\text { *Pod length } \\
\quad(\mathrm{cm} .)\end{array}$ & $\begin{array}{l}\text { *Pod width } \\
\quad(\mathrm{cm} .)\end{array}$ \\
\hline RSG - 991 & 1.63 & 15.15 & 47.15 & 3.42 & 25.11 & 23.16 & 372.45 & 1.76 & 1.04 \\
\hline BG - 256 & 2.14 & 18.29 & 44.67 & 4.61 & 35.62 & 21.62 & 358.12 & 1.78 & 1.02 \\
\hline L- 550 & 2.88 & 20.75 & 50.67 & 5.21 & 29.67 & 25.54 & 355.42 & 1.90 & 0.88 \\
\hline RADHEY & 3.79 & 22.02 & 44.52 & 4.84 & 21.67 & 19.86 & 265.11 & 1.57 & 0.84 \\
\hline GNG - 1581 & 1.36 & 12.19 & 31.78 & 5.81 & 20.41 & 20.44 & 385.67 & 1.40 & 0.76 \\
\hline PUSA- 209 & 4.81 & 24.54 & 44.67 & 6.47 & 26.82 & 22.26 & 261.56 & 1.54 & 0.81 \\
\hline $\mathrm{HC}-3$ & 3.14 & 21.90 & 49.37 & 5.28 & 29.80 & 24.67 & 286.14 & 1.86 & 1.01 \\
\hline CSJ - 515 & 2.47 & 19.14 & 53.63 & 5.83 & 25.42 & 23.15 & 349.24 & 1.64 & 0.94 \\
\hline GNG - 146 & 2.52 & 19.24 & 47.42 & 5.65 & 31.84 & 22.43 & 347.44 & 1.70 & 0.84 \\
\hline$C-235$ & 1.15 & 9.78 & 45.28 & 6.28 & 19.33 & 20.44 & 435.21 & 1.48 & 0.71 \\
\hline PUSA - 261 & 1.82 & 16.67 & 46.67 & 7.47 & 20.67 & 19.85 & 361.75 & 1.58 & 0.84 \\
\hline CSJD - 884 & 1.69 & 15.56 & 44.83 & 6.73 & 21.80 & 22.36 & 366.12 & 1.42 & 0.73 \\
\hline $\mathrm{RSG}-10$ & 4.20 & 22.49 & 51.33 & 5.41 & 34.84 & 21.45 & 296.26 & 1.54 & 0.84 \\
\hline DIGVIJAY & 1.41 & 12.79 & 42.74 & 5.44 & 21.27 & 21.02 & 380.45 & 1.84 & 0.96 \\
\hline GNG - 1491 & 1.59 & 14.77 & 47.89 & 3.80 & 22.67 & 20.44 & 370.45 & 1.89 & 0.96 \\
\hline AKGS - 1 & 2.23 & 19.05 & 35.58 & 5.41 & 26.87 & 19.84 & 344.26 & 1.49 & 0.81 \\
\hline GCP - 101 & 1.93 & 17.69 & 40.62 & 4.83 & 25.67 & 22.36 & 365.26 & 1.51 & 0.80 \\
\hline ANNIGERI - 1 & 2.02 & 18.16 & 43.74 & 6.61 & 26.72 & 21.44 & 351.78 & 1.54 & 0.64 \\
\hline SEm & - & - & 1.12 & 0.13 & 1.59 & 0.71 & 2.81 & 0.19 & 0.13 \\
\hline C.D. & - & - & 3.45 & 0.37 & 4.72 & 2.18 & 8.39 & NS & NS \\
\hline
\end{tabular}

*Average of three replications. 
Table.2 Morphological characters of chickpea varieties/genotypes during 2016-17

\begin{tabular}{|c|c|c|c|c|c|c|c|c|c|}
\hline Varieties/Genotypes & $\begin{array}{c}* \text { Overall } \\
\text { mean no. of } \\
\text { larvae per } 5 \\
\text { plants }\end{array}$ & $\begin{array}{l}\text { * Overall mean } \\
\text { per cent pod } \\
\text { damage }\end{array}$ & $\begin{array}{l}{ }^{*} \text { Plant } \\
\text { height } \\
(\mathrm{cm} .)\end{array}$ & $\begin{array}{l}\text { *Primary } \\
\text { branches }\end{array}$ & $\begin{array}{c}{ }^{*} \text { No. of } \\
\text { pods/plant }\end{array}$ & $\begin{array}{l}\text { *100 grain } \\
\text { weight (g.) }\end{array}$ & $\begin{array}{l}{ }^{*} \text { Average pod } \\
\text { trichome } \\
\text { density } / \mathrm{cm}^{2}\end{array}$ & $\begin{array}{l}{ }^{*} \text { Pod } \\
\text { length } \\
(\mathrm{cm} .)\end{array}$ & $\begin{array}{l}\text { *Pod width } \\
\text { (cm.) }\end{array}$ \\
\hline RSG - 991 & 2.26 & 19.19 & 48.36 & 3.84 & 23.67 & 25.74 & 399.84 & 1.82 & 1.21 \\
\hline BG - 256 & 3.12 & 20.63 & 41.22 & 4.25 & 32.38 & 20.33 & 365.74 & 1.76 & 1.38 \\
\hline L- 550 & 4.77 & 27.02 & 48.95 & 5.32 & 28.33 & 26.89 & 373.52 & 1.84 & 1.04 \\
\hline RADHEY & 5.08 & 28.82 & 41.55 & 4.66 & 25.89 & 20.11 & 324.67 & 1.61 & 0.96 \\
\hline GNG - 1581 & 1.74 & 15.92 & 33.42 & 5.71 & 27.76 & 21.67 & 413.18 & 1.39 & 0.64 \\
\hline PUSA- 209 & 3.97 & 23.71 & 40.37 & 6.35 & 23.52 & 23.84 & 307.26 & 1.48 & 0.93 \\
\hline HC-3 & 4.36 & 26.35 & 47.62 & 5.83 & 27.88 & 26.17 & 327.14 & 1.85 & 0.94 \\
\hline CSJ - 515 & 3.82 & 23.65 & 51.84 & 6.10 & 26.75 & 25.33 & 385.67 & 1.55 & 0.96 \\
\hline GNG - 146 & 3.57 & 23.54 & 49.33 & 5.42 & 29.87 & 23.64 & 359.71 & 1.82 & 0.74 \\
\hline $\mathrm{C}-235$ & 1.32 & 11.12 & 43.16 & 6.56 & 17.84 & 19.67 & 497.71 & 1.65 & 1.17 \\
\hline PUSA - 261 & 2.45 & 19.47 & 44.33 & 6.85 & 21.71 & 18.33 & 401.67 & 1.78 & 0.89 \\
\hline CSJD - 884 & 2.11 & 18.30 & 47.83 & 6.23 & 23.45 & 21.64 & 393.27 & 1.33 & 0.85 \\
\hline $\mathrm{RSG}-10$ & 4.74 & 26.39 & 48.64 & 5.37 & 33.67 & 20.71 & 341.58 & 1.57 & 0.77 \\
\hline DIGVIJAY & 1.52 & 12.79 & 39.45 & 5.88 & 20.81 & 21.33 & 331.82 & 1.92 & 0.95 \\
\hline GNG - 1491 & 2.95 & 20.41 & 45.03 & 3.67 & 23.74 & 22.37 & 426.75 & 1.66 & 1.03 \\
\hline AKGS - 1 & 4.11 & 23.91 & 38.27 & 5.73 & 25.89 & 18.33 & 384.16 & 1.57 & 0.86 \\
\hline GCP - 101 & 3.05 & 20.55 & 42.33 & 4.58 & 24.31 & 23.03 & 391.33 & 1.48 & 0.91 \\
\hline ANNIGERI - 1 & 3.34 & 21.92 & 44.71 & 6.17 & 27.78 & 23.86 & 368.11 & 1.46 & 0.57 \\
\hline SEm & - & - & 1.38 & 0.09 & 1.44 & 0.77 & 2.62 & 0.18 & 0.16 \\
\hline C.D. & - & - & 4.21 & 0.27 & 4.26 & 2.28 & 7.94 & NS & NS \\
\hline
\end{tabular}

*Average of three replications

Table.3 Correlation coefficient (r) of per cent pod damage with physico-morphic parameters during 2015-16 and 2016-17

\begin{tabular}{|l|c|c|c|c|c|c|}
\hline & Plant height & $\begin{array}{c}\text { Primary } \\
\text { branches }\end{array}$ & No. of pods/plant & $\begin{array}{c}\text { Average pod } \\
\text { trichome density }\end{array}$ & Pod width & Pod length \\
\hline \% Pod damage 2016 & 0.313 & 0.091 & 0.148 & $-0.911^{* *}$ & -0.032 & -0.073 \\
\hline \% Pod damage 2017 & 0.175 & -0.014 & 0.087 & $-0.619^{* *}$ & 0.186 & -0.126 \\
\hline
\end{tabular}

* Correlation is significant at the 0.05 level 


\section{Pod width (cm)}

\section{5-16}

An average pod width observed on susceptible check i.e. ANNIGERI-1 $(0.64 \mathrm{~cm})$ was lowest among the varieties under study and a highest pod width of $1.04 \mathrm{~cm}$ was recorded on RSG-991 which was followed by the variety BG-256 $(1.02 \mathrm{~cm})$ and $\mathrm{HC}-3$ $(1.01 \mathrm{~cm})($ Table 1$)$. However, no significant difference with respect to average pod width was observed among the varieties under study.

\section{6-17}

Among the varieties, lowest average pod width of $0.57 \mathrm{~cm}$ was recorded on susceptible check i.e. ANNIGERI-1 followed by GNG$1581(0.64 \mathrm{~cm})$, GNG-146 $(0.74 \mathrm{~cm})$ and RSG$10(0.77 \mathrm{~cm})$. Highest average pod width was observed on BG-256 $(1.38 \mathrm{~cm})$ followed by RSG-991 $(1.21 \mathrm{~cm})$, C-235 $(1.17 \mathrm{~cm})$, L-550 $(1.04 \mathrm{~cm})$ and GNG-1491 $(1.03 \mathrm{~cm})$. These varieties had no significant difference with respect to average pod width (Table 2).

During 2015-16, pod width was correlated as negative and non significant $(\mathrm{r}=-0.032)$ with per cent pod damage whereas positively non significant correlation $(\mathrm{r}=0.186)$ was observed between per cent pod damage and pod width during second year of experiment (Table 3).

These findings are in accordance with results of Kanchana et al., (2015) and Katti and Bhatia, 1993 who reported a positive correlation between pod length, pod width and per cent pod damage.

In conclusion, investigations on the effect of biophysical parameters on the per pod infestation by $H$. armigera revealed that the during two years of experimentation, plant height, number pods per plant and 100 grain dry weight was correlated as positive non significant with per cent pod damage. The number of primary branches per plant was observed to show non significant positive correlation $(\mathrm{r}=+0.091)$ and negative non significant correlation ( $\mathrm{r}=-0.014)$ during 2015-16 and 2016-17, respectively. However, trichome density was significant and negatively correlated with per cent pod damage during 2015-16 ( $\mathrm{r}=-0.911)$ and 201617 ( $\mathrm{r}=-0.619)$. while a negative non significant correlation was observed between per cent pod damage and pod length during both years of experiment. It was observed that trichome density had a significant influence on the pod damage and the moderately resistant varieties i.e. C-235, GNG-1581 and DIGVIJAY had high trichome density.

\section{References}

Anonymous, (2017) Annual report 2016-17 Government of India, Directorate of Pulses development.

Deka, N.K., D. Parshad and P. Chand. (1987) Succession and incidence of insect pests in chickpea, Cicer arietinum L. Giornal Italiano di Entomol. 3: 421-428.

Dua RP, Gowda CLL, Kumar S, Saxena KB, Govil JN, Singh BB, Singh AK, Singh RP, Singh VP and Kranthi S. (2005) Breeding for resistance to Heliothis/Helicoverpa: Effectiveness and limitations. In: Sharma H C (Ed), Heliothis/Helicoverpa management: Emerging Trends and Strategies for Future Research. Oxford and IBH Publishers, New Delhi, India. Pp 223242.

Girija, P., Salimath, M., Patil, S. A., Gowda, C. L. L and Sharma, H.C. (2008) Biophysical and biochemical basis of host plant resistance to pod borer (Helicoverpa armigera Hubner) in chickpea (Cicer arietinum L.). Indian J 
Genet 68: 320-23.

Hasan, M. K. Alam, M. J. and Kamruzzaman, M. (2008) Screening of some chickpea genotypes against Helicoverpa armigera on the basis of physical parameters grown at two locations of Bangladesh. J. Agrofor. Environ. 2(2): 183-186

Hossain, M. Altaf., Haque, M. Azizul and Prodhan, M.Z.H. (2008) Incidence and Damage Severity of Pod Borer, Helicoverpa armigera (Hubner) in Chickpea (Cicer arietinum L.). Bangladesh J. Sci. Ind. Res., 44 (2): 221-224.

Hulse S.H. (1991) Nature, composition and utilization of grain legumes, P. 11-27. In uses of tropical legumes: Proceedings of a consultant meeting 27-30 march, 1989. ICRISAT Centre Patancheru, AP 502-324, India.

Kanchana, R, Lakshmi, K.V and Sekhar, P.R. (2005) Morphological and biochemical bases of host plant resistance to Helicoverpa armigera (Hubner) in chickpea. Journal of Plant Protection and Environment. 2(1):12-17.

Katti, G and Bhatia, V. S. (1993) Preliminary studies on the influence of pod characters on pod damage in chickpea. Indian J Pulses Res 6: 215-16.

Naresh, J.S. and V.S. Malik. (1986) Observations on the insect pests of chickpea (Cicer arietinum L.) in Haryana. Bull. Entomol. 27: 75-77.

Sanap, M.M and Jamadagni, B.M (2005) Screening of chickpea for resistance to pod borer Helicoverpa armigera (Hubner) at Rahuri, Maharashtra, India. ICPN 12: 37-39.

Shahzad, K., Iqbal, A., Khalil, S. K. and Khattak, S. (2005) Response of Different Chickpea (Cicer aritinum) Genotypes to the Infestation of Pod Borer (Helicoverpa armigera) with Relation to Trichomes. Research Journal of Agriculture and Biological Sciences 1(1): 120-124.

Sharma HC, Pampapathy G, Lanka SK and Ridsdill-Smith TJ. (2005) Antibiosis mechanism of resistance to pod borer (Helicoverpa armigera) in wild relatives of chickpea. Euphytica 142: 107-117.

Singh, H., Mahajan, G. and Singh, I. (2004) Efficacy of different insecticides against gram pod borer (Helicoverpa armigera) on chickpea (Cicer arietinum L.). Legume Res., 27: 233-234.

Taggar GK and Singh R. (2012) Integrated management of insect pests of rabi pulses. In: R Arora, B Singh and AK Dhawan (Eds), Theory and Practice of Integrated Pest Management. Scientific Publishers, India. Pp 454-72.

\section{How to cite this article:}

Rakshith Roshan, D. and Raju, S.V.S. 2018. Influence of Morphological Characters of Chickpea Varieties on Damage by Gram Pod Borer (Helicoverpa armigera Hubner). Int.J.Curr.Microbiol.App.Sci. 7(12): 2025-2033. doi: https://doi.org/10.20546/ijcmas.2018.712.233 